\title{
HISTORICAL AND PHILOSOPHICAL DISCOURSE OF MUSIC ORATORY IN THE PROJECTION OF DOMRA PERFORMANCE
}

\section{Oliinyk O. L.}

\section{INTRODUCTION}

Science and at the same time the art of oratory, which originated in the «cradle of European civilization» - antiquity, was re-interpreted in the septem artes liberalis, the heart of the Christian wisdom in the Middle Ages, subsequently lost its leading position, giving way to other philosophical studies. Its intense revival happened unexpectedly in the last century, when oratory was again widespread in the sociocultural environment and revealed its practical essence in the processes of modern communication. The researchers also point out the natural need of technocratic age people to find the best forms of communication and note several major causes of the rapidly growing popularity of oratory. It is noteworthy that these causes are found in different ways of spiritual and social life and have both intellectually communicative and purely pragmatic characteristics.

Going back to the historical origins, we find that in the Ancient times two basic traditions of oratory were formed. The first tradition is most vividly represented in the works of the Ancient Greek philosopher Aristotle (IV century BC). Within it, oratory is defined as «the art of persuasion.» According to this tradition, the main task of the speaker is to convince the audience.

The second tradition is most vividly represented in the works of the Ancient Roman orator Quintilian (I century AD). Within it, oratory is defined as «the art of speaking gracefully.» According to this tradition, the speaker's job is beauty, sophistication, and elegance of expression. Persuasion appears to be possible, but not by far the main purpose of the speaker ${ }^{1}$.

1 Колотілова Н. Риторика: навч. посібник. К.: Центр учбової літератури, 2007. C. 11. 
The Christian tradition of oratory is manifested through the central position of science and art at the same time in the system of the trivium (grammar, oratory, dialectic), where the metaphysical normativity of grammar is revealed as the starting point, and the philosophy of development, i.e. dialectics, is the final summation.

\section{Principles of speech and its impact on musical performance}

«XX century is the century of personification of personality, that is, the individual identity of the individual, growing dissimilarity of each individual from the others. This dissimilarity increase leads to complications in communication between people and thus causes the need for a society in a science called oratory which aims to teach people to communicate",

The second reason for the current actualization of oratory as a science is the expansion of public spheres of oral communication, the increase of channels of transmission of oral information (radio, television, in recent years - public networks):

«The purely communicative reasons for the revival and development of the language influence science of the twentieth century can be attributed to the development of communication itself. Our time is characterized by a dramatic expansion of the sphere of communication of people, an increase in the number of situations in which we must engage in communication and convince each other. The meaning of oral language has expanded significantly, it is beginning to perform more and more diverse functions, and is playing an increasingly important role in society, which in turn leads to the need to find new ways of communication, to pay more attention to different styles of communication", 3 .

Finally, the third reason for the need to master the art of oratory is called the economic realities.

The structure of oratory perfectly takes into account the psychological nature of human perception, the ability of thinking to build a logical chain in the grasp of every communicative object that is the focus of attention of both the author and the recipient.

\footnotetext{
${ }^{2}$ Бондаренко В. Риторика. Харків: Вид-во ХНАДУ, 2008. С. 8.

${ }^{3}$ Бондаренко В. Риторика. Харків: Вид-во ХНАДУ, 2008. С. 9.
} 
The traditional five parts of oratory (Inventio, Dispositio, Elocutio, Memoria, Pronuntatio) ${ }^{4}$ are opened by a stage of primary design, concentrated in the knowledge and skills of Inventio - invention. They determine the qualities of the four further components of the oratory whole: the art of «continuation» once given as an oratory theme at the level of high abstraction. Speech orientation of the oratory leads to «ubiquity of legato» ${ }^{5}$ in the interaction of ethos and the affect of oratory expression, which is the special content of the fourth part of oratory Memoria.

The verbal nature of oratory after defining the main tasks in Inventio is based on the doctrine of Dispositio (teaching) and Pronuntatio (action); in the first of them the logical differentiation of the oratory speech is followed to the greatest extent, while in the latter the physical features of verbal presentation (facial expressions, diction, declamatory principle, gesture, etc.) are working.

The application of compositional principles of the oratory in various fields of human activity, including fine arts or music involves a careful preparation and process professionalization of the chosen kind of activity, one way or another related to communication and broadcasting, and more broadly to the correct presentation of the related text. This constitutive property of the oratory principles is clearly outlined in the first stage: the invention, since it requires such an arrangement and structuring of the original idea in a verbal (or non-verbal) form, which will be convincing and clear in the subsequent process of presentation and argumentation.

For the evolution of a tool that integrates from the folk to the academic sphere, it is very important to learn the type of composition that operates the techniques of logical construction of artistic integrity and unlike the spontaneous improvisational mode of folk music it applies the detailed and proven principles of development.

The purpose: «to propose a whole set of provisions and in such a sequence that they do not contradict each other, but specifically move from one part to another until a legitimate conclusion» ${ }^{6}$ first of all sets

4 Захарова О. Риторика и западноевропейская музыка XVII - первой половины XVIII века. М., 1983. С. 34-40.

5 Захарова О. Риторика и западноевропейская музыка XVII - первой половины XVIII века. М., 1983. С. 37.

${ }^{6}$ Мацько Л. Риторика: навч. посіб. 2-ге вид., стер. К.: Вища школа, 2006. C. 45 . 
itself the second section of oratory, disposition, beginning the stages of development and demonstration of the main ideas formulated and outlined in Inventio.

Despite the clarity and transparency of the logical and structural rules of oratory, they are by no means schematized in scholastic unambiguous terms, but have a proper sense of semantic entropy, which focuses primarily on the Elocutio stage.

«Elocution (Latin eloguor - I say, teach) is the third section of classical oratory, which reveals the laws of linguistic expression of the subject of communication. The main sense of elocution from classical rhetoric has gone into modern stylistics (the doctrine of styles and the doctrine of tropes and figures). The first and the second stage development, the inventions and dispositions, has become a linguistic figurative expression and, as a result, an additional substantive, evaluative, emotional, volitional effects.

To conclude our review of the oratory stages, let us focus specifically on the last, fifth level, Pronuntatio. It is also extremely important for the rhetorical foundations of music art because, being a process of text pronounciation, the oratory speech draws a direct analogy to musical interpretation. Contemporary writers of oratory consider that «the most important is the fifth stage of the oratory activity, which is the making a speech ... At this stage, the speaker should best present the result of his work to the audience performed in the previous stages. In other words, one can write a variety of texts very well, but not be able to present them to the audience.

The important predisposition of the use of rhetorical principles in relation to performing, particularly in playing the domra, is stating the exceptional role of non-verbal means on the stage of Pronuntatio, that is, those funds that constitute the essence of the musical interpretation, those that convey to the listener the text of a musical work through individually selected techniques. They correspond with those components which are defined as "verbal unit" in oratory. "The signs of non-verbal communication include the language of gestures and postures; language expressions; paraverbal characteristics; language space; language of clothes and the language of colors etc.» ${ }^{7}$.

7 Колотілова Н. Риторика: навч. посібник. К.: Центр учбової літератури, 2007. C. 113. 
The rhetorical foundations of the European art of professionalism and musical performance in particular is historically visualized: it is the sphere of sacred music that became the main centre enhancement and conservation, the incentive for professional musicians. However, the historical context of the oratory ascents to a leading position in the musical art of Renaissance and Post-Renaissance art space being a Testament to the specific needs of the rhetorical affirmation of art in the background of the musical germs of secularization. The primary symbols of thinking like abstraction, circles, arcs, lines have obtained the basic position $^{8}$ and they note the possibility of the melodic heterophony expression.

The embodiment of the ideal essence of music is the Pythagorean table of altitudes of diatonics, in which the celestial perfect representations and «elements» (water-fire-air) of «rarefied matter» are the worthy incarnations in music: «diapason spiritus» (abc), «diapason medium» (d), «Diapason materialis» (ef). The above demonstrates «musical metaphysics», abstract expressiveness as the bearer of «aboveground joys». Any «approach to the earth» in music required a «divergence» of representation, similar to the fluidity of the material manifestations of the «elements». According to the latter, the most significant symbolic figures of rhetorical presentation, as shown in O. Zakharova's book, are: «rotacio» - rotation, circle, «suspirio» «breath», arc, «anabasis-catabasis», the ascending and descending line, also contain the figure of «fuga» or «running», that is, «movingspreading» altitude at different levels of «conditional space» of music.

In these gradations of the oratory symbolism, the levels of spiritusmedium-materialis are recognizable: the circles or arcs are the symbols of Everything, God, the lines are the «borders» of the worlds, the fugue is the "element of tone», whose «melodic energy» of movement «moves» in the artificiality of the music space. However, these basic and «elementary» figures of musical rhetoric do not form the essence of the possibilities of the «art of speech»: the specifics of the subject semantics of verbal speech, its ability to involve in the visual representations or images testify to the specifics of the oratory deployment in music.

F. Chivra's book directly emphasizes that the very polemicy of humanism against the abstraction of the logical school and the strictly

${ }^{8}$ Гудман Ф. Магические символы. М: Издат.Ассоц.Духовного объединения «Золотой век», 1995. С. 25-28. 
spiritual status of the music law is put forward by an «alternative to rhetoric» as a «science of language,» immersed «in the variety» of «dimensions and qualities of real» dimensions and qualities. The historical projection draws to the identification of poetics and oratory that comes from Plato and Aristotle to Campanella, pointing to the organism of the presence of philosophical knowledge in poetics, especially in sophistry ${ }^{9}$.

The central position in oratory belongs to Elocutio as the doctrine of verbal figures, the techniques of the tropes, that is the verbal combinations or carriers of the super-verbal semantics «colorita», «ornata», «fiorita» ${ }^{10}$. These general provisions of oratory are given here for the sake of accentuating the poetic load of language art, which determines the historical regularity of replacing rhetoric with poetics as a specifically artistic sphere.

As S. Ship correctly points out about the dangers without critical use of the oratory categories in musicology and interpretation, the category of musical oratory must first and foremost be consistent with theoretical ideas about musical language. The concept of rhetoric is meaningful only if it is clearly distinguished from the concept of language. Speech is subordinated primarily to language, i.e. the laws and norms of phonology, morphology, word formation, and syntax. It is expedient to consider the oratory only as a tier of organization of form and content that «builds» over the linguistic order of speech» ${ }^{11}$.

Moreover, the scientist puts forward a number of necessary requirements for the use of rhetorical categorical apparatus for musical artifacts by modern researchers: «The hermeneutical application of the doctrine of the musical oratory requires a specialist: a) the inferior knowledge of the primary sources, the texts that represent this doctrine; b) the systematic theoretical understanding of the linguistic and compositional construction of artifacts of the music speech; c) the art of

${ }^{9}$ Civra F. Musica poetica. Introduzione alla retorica musikale. Torino: UTET Liberia, 1991. C. 19-21.

${ }^{10}$ Civra F. Musica poetica. Introduzione alla retorica musikale. Torino: UTET Liberia, 1991. С. 36.

11 Шип С. Методологическое значение доктрины о музыкальной риторике в немецком и украинском музыкознании (Methodologische Bedeutung der Doktrin von der musikalischen Rhetorik). Музикознавство у діалозі (Musikwissenschaft im Dialog) / Київьке музикознавство (Kiewer Beitrage zur Musikwissenschaft). Київ - Dusseldorf, 2011. Вип. 37. С. 36. 
conceptual interpretation of music, and in particular, a deep understanding of the meaning of musical forms and a sense of balance in expressions" $"$.

The definitions of oratory, both as science and as art, and especially the considerations concerning the peculiarities of the use of the categorical apparatus of oratory in the analysis of musical artifacts, assure that the oratory terminology, as well as the approaches formed by it, should be used with great care and thought. S.Ship's warning against the thoughtless application of rhetorical terms to any arbitrarily choice of musical expressive reception or rhythm and intonation is quite reasonable. The categorical apparatus of the oratory can only be applied within strictly appropriate frameworks of analysis of styles and genres. On the other hand, the methodology of musicological analysis, based on rhetorical approaches, gives convincing results and allows to reveal some deep layers of content and logical mechanisms of construction of the work.

In a study dedicated to the performer's interaction with the modern process of professionalization and academization of the art of playing the domra, the oratory categories seem appropriate to justify the basic provisions. However, from all the diversity of rhetorical components that have been formed and theoretically decommissioned in the musicalaesthetic heritage over several centuries, only some of the most convincing and necessary are selected.

They are:

- the invention as a fundamental impulse of the creative process of both composer and performance; it involves a preliminary perfect (that is, centered in the ideal design of the composer or performer) model that will consistently be embodied in a fixed musical text or performance concept;

- the concept of rhetorical disposition as a structure-forming principle that ensures the logic and integrity of musical construction (according to the above interpretation of this special section of rhetorical science, aimed primarily at the correct organization of the text, ensuring the flawless logic of its composition);

12 Шип С. Методологическое значение доктрины о музыкальной риторике в немецком и украинском музыкознании (Methodologische Bedeutung der Doktrin von der musikalischen Rhetorik). Музикознавство у діалозі (Musikwissenschaft im Dialog) / Київьке музикознавство (Kiewer Beitrage zur Musikwissenschaft). Київ - Dusseldorf, 2011. Вип. 37. С. 42. 
- transfer of the rhetorical component of the correct composition to the composing and performing process in the art of domra play, as it provides an individually creative component of the text construction («the content of speech is included in the paralogy, which allows the use of words and expressions in a figurative sense») and even more so it seems natural and necessary in the compositional principles of artistic (including musical) artifacts;

- taking into account all the wealth of the non-verbal complex of the rhetorical element of «action - Pronuntiatio» in the sphere of interpretation as one of the fundamental ones in the formation and theoretical awareness of the rhetorical load of certain performing techniques of playing at home.

As we can see, from the whole oratory compendium, the concepts that characterize the logical arrangement of the elements of construction and relate to the oratory load of the techniques of playing domra, are involved in the categorical apparatus of the dissertation. Their use seem necessary due to the fact that the incorporation of the oratory principles into the logical laws of constructing a piece of music both fixed (composer level) and sounding (performing level) are formed since the Renaissance and Baroque times. Therefore, their use in home-grown art and performance confirms the tendency to professionalize and academize the folk instrument.

\section{The impact of rhetorical forms on the development of the performing arts of domra}

In this study, we must follow the rhetorical foundations of the instrumental thinking of the domra players, which by virtue of certain historical conditions have preserved the continuity of the performing and composing activities that were mediated in the field of other academic instruments by a narrow specialization of civilization. Although much of the great composer's discoveries were made by the efforts of the artists who combined the skills of a composer and a congenial performing activity, those names are too well known to be repeated. Nevertheless, the classical music of the $18^{\text {th }}$ and $19^{\text {th }}$ century aimed to determine the prevailing significance of the composer's own.

Comparing the above historical information, the following preliminary conclusions are drawn:

1) the slaughtering in Russia was organically connected with the traditions of the ancient Christian church, marked by special religious 
ideas of the Cyril and Methodius tradition, the expression of which is found in the frescas of Sofia in Kyiv;

2) the relation between skomorokhs and the pan-European tradition of highly professional training of Christian bards, formed in the conditions of the early Cossack era within the Lithuanian-Kyiv statehood of the XIII-XIV House of Music.

3 ) the string-plucking performance of the skomorokhs in the context of connection with the early Christianity, is perceived as being in harmony with the traditions of spiritual music, in contrast to the later setting of Orthodoxy (and Catholicism in the period of counterreformation) to the profane the nature of instrumentalism;

4) the historical intertwining of the socially religious and politically religious foundations of life and musical creativity in Ukraine, where the rhetoric of instrumental art, which territorially imitated the skills and abilities formed in Kievan Rus, formed the educational basis of the selfaffirming activity of the nation.

It is known that the adoption of Christianity by Byzantium advanced the very beauty of Divine Service, especially church singing, the perfection of which was the pledge of the attachment of human essence to Heaven, to the Divine essence. Here again we notice the importance of the early Christian tradition, the polyphonic singing of the Irish monks who baptized Russia ${ }^{13}$ ). Church Fathers, Rhetoricians and Gymnasts Andrey Crete, John Damaskin, John Chrysostom and others in the purity of the musical expression of the syllabic verse and its intonation inspired embodiment in the singing of hymns saw the essence of the manifestation of the Christian mood of the soul. And if the Law of God first formed the Word, and the clarity of the verbal presentation of the text was and remains the basis in the Orthodox Christian singing, then its musical embodiment has always been an integral part of this verbal form as a sign of inspiration, the superstitious expression of everyday speech.

The rhetoric of reading of sacred texts begins with the subtlety of its sounding, and the psalmodic reading of such a text by the very subtlety of sound saturated with an attachment to the Supreme. For that there is the supernatural tonaliaty that deliberately distanced such a sound from the vital «sonar filling» that forms the basis of the religious symbolization of what the text proclaims.

13 Лихачева В. Искусство Византии IV-XV веков. Л.: Искусство, 1986. С. 29. 
The oratory ornaments of the sacred text, laid down by the practice of hymn singing, which distinguished the Eastern Church tradition from the prose of rationalized liturgical activity in the West, were the signs of involvement in the Supreme. This adornment of the word (not in the literal sense), added precisely by the music, its tone, eventually gave birth to a church «aria» that preceded the opera and testified to the superstitious inspiration of reading and singing verbal, poetic lines. After all, the first troparians emerged from the free poetic translation of biblical images, forming the tradition of the Christian East, while the introduction of tropes into the Western Church, stimulated by the heirs of Byzantium in the St. Gallen Monastery, was the starting point for the development of artistic ornament in the church singing.

The very beginnings of the composition, that is the elements of the composer's work, stood out in the process of trapping, because by composing verses for established alleluia chants in the Western Christian version, or forming condos from a set of verses in the Orthodox tradition, the singers built a form different from the original one.

The rhetorical principle of composition began with a «rhetorical emphasis» by musical means, which is a repetition of meaningful turnover, that gave the effect of «fugue» in a polyphonic texture ${ }^{14}$. One way or another, the musical outputs in the presentation of the text in the process of liturgy performed and still perform an independent important meaningful function. Although it is an «elementary» (in terms of artistic possibilities of imitation of life sound expression) psalmization, it is the embodiment of the high sense of the One as a manifestation of the high capacity of the ideal intellectual tension of the energy of thinking, which exists outside the defined world of facts and concepts.

The author of the book "Myth and Ritual in Christianity" A. Watts notes the following: "since the time of Hilbert, mathematicians have no longer attempted to define the point". Specifying the depth of the paradox of our conceptions of knowledge, he adds: «Modern science has resigned itself to the fact that it has to operate alongside fundamental, unknown, marked concepts without precise definitions ${ }^{15}$.

In the symbolic dimensions of the world of religion and art, «point» is a factor of the utmost importance of expression: for «a graphically

${ }^{14}$ Civra F. Musica poetica. Introduzione alla retorica musikale. Torino: UTET Liberia, 1991. C.42.

15 Уотс А. Миф и ритуал в христианстве. К.-М.: София, 2003. С. 66. 
represented circle with a dot in the center indicates the center of the infinite or the root cause» ${ }^{16}$. And if in the art of painting there is a legend about the «points» displayed by the hand of a master on a portrait sketch of a student who made the last imprint of living eyes, then the basic reality of this art of painting becomes a line as a set of points. And in music the self-importance of tone-point as the center of expression of musical essence is evident from the «primitive» of the studios to the virtuoso skills of «taking» the inaccessible notes of the composite whole.

Considering the myth a true «revelation of the power of the Lord» ${ }^{17}$, and religious Christian doctrines by the union of mythology and science. «... Christian dogma is a mixture of ancient Jewish mythology and history with Greek metaphysics and science ...» ${ }^{18}$, A. Watts considers «poetry and myths» the embodiment of the «real world», in contrast to the «dead world» of what was or will be, that is, the world of scientific factology. The reality of the «miracle of music», a mystical phenomenon centered on singing, but based on an instrumental start. And the latter embodies an outlet for the «natural» speech range, as Isidor Seville noted $^{19}$.

In this connection it becomes clear, and the caution with which the Orthodox thinker, the representative of musicological science Martynov speaks about the difference of the linear «delicacy» and nevma marked «phonemes» of ancient Church music. The victory of the all-sufficient physical power is manifested in tone and originates in the depths of the European Renaissance materialist world, in which physical reality is the criterion of truth and life reliability. And on this wave of growing of nationalist materialistic culture breakthrough stringed instruments approved «recast» human detection in the world, pushing the symbolism of a plucked sound with its delicate «touch» to the altitude that continues with the sound quality of the rehearsal efforts in tramelan.

Sound became the basis of mundane and profane music and the evaluation of it has found the subject material sense which is different from the ideal abstraction of sacred and Church music. For a professional musician the sound became a way of artistic communication, from what a «bad» sound is aesthetically obliged by the incompleteness of the

${ }^{16}$ Большая энциклопедия символов и знаков / Сост. А. Егазаров. М.: АСТ, 2007. C. 676.

17 Уотс А. Миф и ритуал в христианстве. К.-М.: София, 2003. С. 72.

18 Уотс А. Миф и ритуал в христианстве. К.-М.: София, 2003. С. 65.

19 Уотс А. Миф и ритуал в христианстве. К.-М.: София, 2003. С. 26. 
artistic ideal performance. Many instruments sound «ready» (piano, accordion...), while the other instrumental conditions (to a large extent and the sound of the domra) the sound generated by the contractor and intonation, and linguistic and sobralinho subject. But even in the case of direct dependence of instrumental intonation, the quality of instrument (Bayan-accordion, for example) the sound quality depends on the ability of a performer to «pull it out», but on the domra this is the basis of music performance. Therefore, clearly recognised the «success story» by the domra as a result of a lot of care and interest of the contractor in the produced sound.

The quality of sound is determined by its timbre, and the nature of the latter depends on one or another overtone, as well as on the strength of its detection, when it comes to the post-Renaissance stage of the formation of music as «sound-painting art», the art of «harmonious expressiveness») of sound (overtones are the analogous to perspective in painting).

In line with this concept of parallels of music and fine arts has been studied by many scientists, including this study by G. Helmholtz and K. Stumpf. Pointing to overtones as the cause of timbre, according to G. Helmholtz, we make the following conclusions:

- The overtone scale from the first to the sixth is the main basis of musical sonority and timbre;

- Overtones above the sixth give sharpness and hardness to the sound;

According to the conclusions of K. Stumpf, the dependence of the timbre on the overtones is explained as follows: by the coloring, the steps of the overtone scale move from a thick, filled color to a transparent and light color, from the darkest to the brightest. Consequently, the coloration of a sound consists of the coloration of its tones, and the accompanying noises greatly affect the purity of the timbre resulting from the overtones.

Thus, deliberately altering the conditions that determine the overtone structure of the sound, by academic school, as it now is by domra, actually controls the sound quality, which is obtained on the instrument. But a good, clean sound is not the only task. Art also requires a great variety of shades of the sound including their ideal «resembalnce» that reduces to the Genesis of plucked instruments. In this case, we are approaching the musical «mythologism», sonically fleshing out the impossible and the unknowable. 
To the X-XI century in the Celtic countries there has been established the role of the bard as a carrier of folk performing traditions, the Keeper of traditions and folk wisdom. Bards created a special layer of the artistic society, independent in a certain sense. No event in the life of the people or in the life of an individual is complete without their participation, whether it is war, feast, wedding or funeral.

The bandore sound of the XV-XVII centuries was marked not as directly by the «revival of antiquity» as by the harmony of anti-Christian and Christian religiosity that occurred in early Christianity (the era of «musical revival» by K. Kuznetsov ${ }^{20}$ ) and was rejected by the iconoclastic rigorism. The Middle Ages culture also acted as a viable alternative to the Renaissance renewal, beginning with the Carolingian and Macedonian Renaissance of the VIII-XII and IX-XIII centuries ${ }^{21,22}$. After the anti-religious and anti-Church orientation of scientific and artistic activity of the New time the end of XIX century demonstrated the revival of the harmony in the creative and religious spheres, which was most clearly expressed by the symbolic theorist A. Bergson ${ }^{23}$, pointing to the identity of the method of art and religion.

The action of V. Andreev, carried out with the help of the Ukrainian cultural aura under the real conditions of his activity, gave life to the academic domra music. It took place in the context of the symbolic achievements of the «Silver Age» (1888-1896), reproducing in the orchestra's structure as a symbol of victorious European musical academy, the sound of fundamentally non-orchestral, namely, ensemble «replacement singing» instruments, which by its nature was Renaissance music.

If one accepts that the idea widespread in contemporary cultural studies and the anthropology of music, saying that "the frameworks within which the music system change takes place depending on the sociocultural environment. This observation is true even where the music

20 Кузнецов Б. Путешествие через эпохи. Мемуары графа Калиостри и записи его бесед с Аристотелем, Данте, Пушкиным, Эйнштейном и многими другими современниками. М.: Молодая гвардия, 1976. С. 40.

21 Каролингское возрождение [Электронный ресурс]. Режим доступа: https://ru.wikipedia.org/wiki/Каролингское возрождение

22 Лихачева В. Искусство Византии IV-XV веков. Л.: Искусство, 1986. C. 99-133.

${ }^{23}$ История философии: в 4-х томах / Под ред. М.А. Дынника, М. Иовчука и др. М.: Изд. АН СССР, 1957. Т. 1. 1957. С. 715-716. 
is sought to be regarded as an autonomous entity" 24 , some of the cultural and historical changes occurring in the spread of domra and other instruments of this group become quite clear. The «pointilistic» nature of sound on stringed pluckers in the Andreev Orchestra corresponded to the pointilist findings in the painting at the beginning of the 19th and 20th centuries (J. Sora, P. Sinyak) and the attempts of A. Webern's musical pointillism, as well as the psychological-pointillist view of the world as a series of «sensations» in the influential E. Mach University philosophical neo-positivist concept. And similarly to how the painting of postimpressionism and symbolism made sense of the appeal to the reviving values of icon painting and the mosaic art related to it, so in the musical sphere of the 19th-early 20th centuries. There was an appeal to Schola cantorum in France, to the vocal polyphony in S. Taneyev and M. Leontovich in Russia and Ukraine, to the pre-Peter music, which included Ukrainian-Cossack artistic heritage, which obviously inspired V. Andreev.

It makes an inevitable conclusion that the symbolic nature of the old tools, is fundamentally different from the intelligible «anthropocentric» music of the New time. Above the genre system of the last century is characterized in accordance with the archetypology of the structure of mass in their semantic direction to the orchestra sound. In this typological load the duality of values has been expressed: the inclination to ecclesiastic genres, but with demonstrative opening of their liturgical content. This «Neorenaissance» worldview is different from goal setting the Creator of the «orchestra of folk instruments»: on the one hand, demonstrative preserving the purity of the folk tradition, on the other hand, the voluntaristic creation of the team of specialists, training testified about his involvement in the academy.

The paradox of a thought by A. Watts about the «reality» of myth and «dead» in the generalizations of matter allows us to understand the significance of the musical component in human expression, even if it is only one pitch in the psalmodic representation of the text. Incarnation in tonal dimensions of «things» and «facts» of what is called «reality», and Watts identifies as «the dead world», in musical and artistic expression gives the perfect combination of «living» and «dead», real instant and accrediting conceptual integrity of the tone of one or another image.

${ }^{24}$ Dobberstein M. Musik und Mensch. Grundlegung einer Anthropologie der Musik. Berlin: Dietrich Reiner Verlag, 2000. C. 13. 
Born with effort due to V. Andreev, the orchestra of folk academic instruments, responding to the demands and urges of the time, found itself in the situation of the heir to the orchestral traditions of Greece and the Italian South, that is, it was the representative of the polar opposite tradition to the most widespread and glorified European music at that time.

This reasoning focuses on the «elementary oratory» of sound production performed on a specific instrument, followed by the pathos of the oratory presentation of sound which is imparted by the material character of the material from which the instrument is built. Hence the «vitality» of strings of the instruments of ancient ritual, since the strings resembled the nerves, the body, the human body, and the correct mood of the strings symbolized the harmony of the soul and body of human creation $^{25}$.

The basis of the artistic approach of the authors of Antiquity was the idea of «mimesis», i.e., «imitation», which occured in post-Renaissance European conception of realism in art: «imitation of life», «the second reality» as «assimilation» to recove reality of the human environment and that the material-spiritual nature of human kind.

If the first side of the mimetic activities are usually distinguished terminologically speaking about realism in artistry, then the second is associated with the beginning of symbolic thinking and art. Moreover, this symbolic side of mimetic activity was for the ancient Greek philosopher of the base that forms the Foundation of mental activity in General, and in her music it was the «trigger». This is determined solely by the responsible function of music and music education in society: «music being the gymnastics of the soul», «music as gymnastics of the intellect» as a logically and intellectually created the leading sign of the ancient «soul» that harmonizes with the body ${ }^{26}$.

The basis of this mental setup is the Church's symbolic worldview, giving rise to an oratory model, significantly different from the verbal rhetorical principles of Antiquity, designed to develop a hierarchy of affects.

25 Холл М. Энциклопедическое изложение масонской, герметической, каббалистической и розенкрейцеровской философии. М.: Эксмо; СПб.: Мидгард, 2007. С. 72-74.

${ }^{26}$ Музична естетика Античної Греції. Вступний нарис $i$ зібрання текстів О.Ф. Лосєва. К.: Музична Україна, 1972. С. 18-36. 


\section{CONCLUSIONS}

The symbolism of «the imitation of ideas» was adopted in the numerical concept of the world of Harmony, which in ancient philosophy was formulated by Pythagoras. In this field he laid the foundations of metaphysics, i.e. teaching about the obvious signs of unchanged integrity of the world and continualist thoughts. The projection of the mentioned positions in the plane of instrumental music provides the differentiation types of tools to those that are primarily associated with the material integrity of the world, and those that are able to convey the spontaneity continuum of thought. As for the tempo-virtuoso range of the string group, he definitely belongs to the second group and, as shown in the previous subsections can understand rhetorical elements of the speech origin. It is known that musical rhetoric refers to almost all genres and forms, as vocal and choral, theatrical, and instrumental. But the plucked string group, including domra as one of its characteristic tools reports the rhetorical techniques in a very indirect way, in the conventional plane ideal image.

Domra, having enterecd the field of academic instrumental performance relatively late, has kept the tradition of the unity of the «composer-performer» much more than other academic tools. This is due to the lack of respectable academic repertoire for domra and the entrenched practice of performance, which provides in its art the result of improvisation, spontaneous component, the need to add something from himself» to famous works already in the process of interpretation.

This seems to be the preservation of the syncretic traditions of musical art that has existed for many centuries and only relatively recently has lost its relevance, giving way to a differentiation of creative activity of the composer, performer and teacher.

A historical and stylistic discourse of creativity for the mandolin, which we interpret as the tool is fundamentally intertwined with the domra in Western timbre compendium, as well as for the dobro in a chronological interval from the XVIII to the XXI century. The Mandolin, which is very diverse, given its rich imagery and emotional and expressive features is used by the composers of the past and present from A. Vivaldi to M. Skoryk, by its nature, detects close to domra, particularly with regard to rhetorical speech virtuost characteristic of both tools and techniques.

Domra, which was prevalent in musical practice, mainly on the wave of symbolism of the Silver Age in the Russian culture during the centuries of its intensive development course combined the academic 
trend that some previously put on the mandolin with the folk origin, but has not lost the characteristics of national instruments, sensitive to the innovative stylistic trends to be active in search of innovation, and experimental for the 21 century $^{27}$.

\section{REFERENCES}

1. Большая энциклопедия символов и знаков / Сост. А. Егазаров. M.: АCT, 2007. $723 \mathrm{c}$.

2. Бондаренко В. Риторика. Харків: Вид-во ХНАДУ, 2008. 121 с.

3. Гудман Ф. Магические символы. М: Издат. Ассоц. Духовного объединения «Золотой век», 1995. 289 с.

4. Захарова О. Риторика и западноевропейская музыка XVII первой половины XVIII века. М., 1983. 77 с.

5. История философии: в 4-х томах / Под ред. М.А. Дынника, М. Иовчука и др. М.: Изд. АН СССР, 1957. Т.1. 1957. 717 с.

6. Каролингское возрождение [Электронный ресурс]. Режим доступа : https://ru.wikipedia.org/wiki/Каролингское возрождение

7. Колотілова Н. Риторика: навч. посібник. К.: Центр учбової літератури, 2007. 232 с.

8. Кузнецов Б. Путешествие через эпохи. Мемуары графа Калиостри и записи его бесед с Аристотелем, Данте, Пушкиным, Эйнштейном и многими другими современниками. М.: Молодая гвардия, 1976. 190 с.

9. Лихачева В. Искусство Византии IV-XV веков. Л.: Искусство, 1986. $310 \mathrm{c}$.

10. Маркова Е. Неоевропоцентризм и неосимволизм начала XXI века. В. Холопова, Л. Канарис, Е. Маркова, С. Таранец. Неоевропочентризм: музыкальная культура на рубеже столетий. Книга 1. Одесса: Астропринт, 2006. С. 76-128.

11. Мацько Л. Риторика: навч. посіб. 2-ге вид., стер. К.: Вища школа, 2006. $311 \mathrm{c}$.

12. Музична естетика Античної Греції. Вступний нарис $i$ зібрання текстів О.Ф. Лосєва. К.: Музична Україна, 1972. 322 с.

27 Маркова Е. Неоевропоцентризм и неосимволизм начала XXI века. В. Холопова, Л. Канарис, Е. Маркова, С. Таранеи. Неоевропочентризм: музыкальная культура на рубеже столетий. Книга 1. Одесса: Астропринт, 2006. C. 76-128. 
13.Покровская Н. История исполнительства на арфе: Курс лекций [для оркестровых факультетов (струнное отделение) музыкальных вузов]. Новосибирск, 1994. 351 с.

14.Уотс А. Миф и ритуал в христианстве. К.-М.: София, 2003. $240 \mathrm{c}$.

15.Холл М. Энциклопедическое изложение масонской, герметической, каббалистической и розенкрейцеровской философии. М.: Эксмо; СПб.: Мидгард, 2007. 864 с.

16. Холопова В. Музыка как вид искусства. М.: Научно-творч. центр «Консерватрия», 1994. 260 с.

17.Шип С. Методологическое значение доктрины о музыкальной риторике в немецком и украинском музыкознании (Methodologische Bedeutung der Doktrin von der musikalischen Rhetorik). Музикознавство у діалозі (Musikwissenschaft im Dialog) / Київське музикознавство (Kiewer Beitrage zur Musikwissenschaft). Київ Dusseldorf, 2011. Вип. 37. С. 23-49.

18. Civra F. Musica poetica. Introduzione alla retorica musikale. Torino: UTET Liberia, 1991. 215 p.

19.Dobberstein M. Musik und Mensch. Grundlegung einer Anthropologie der Musik. Berlin: Dietrich Reiner Verlag, 2000. 150 s.

Information about the author: Oliinyk O. L., Rector, Ph.D. in History of Arts, Professor at the Department of Folk Instruments, Odessa National A. V. Nezhdanova Academy of Music 63, Novoselskogo str., Odessa, 65023, Ukraine 